\title{
II Monastero camaldolese degli Angeli e la Rotonda di Brunelleschi: possibili connessioni
}

Marcello Scalzo

Abstract

Attraverso la lettura del testamento redatto dai membri della famiglia Scolari, si ipotizza la localizzazione e la forma della Rotonda degli Angeli, edificio a pianta circolare realizzato da Filippo Brunelleschi dal | 434 al | 437 rimasto però incompiuto. Si ipotizza la sua collocazione nel tessuto urbano fiorentino risalente ai primi decenni del XV secolo, e di come l'architetto (interpretando le indicazioni testamentari sugli spazi da occupare) realizza l'edificio non in adiacenza al Convento esistente, ma discostato, all'incrocio di due importanti assi viari, collocandolo in una posizione decisamente rilevante del tessuto urbano. Si ipotizza inoltre l'eventuale collocazione di uno o più porticati, la cui costruzione era originariamente prevista nel lascito testamentario. Si investiga, inoltre, sull'esistenza di disegni e modelli realizzati in origine dal Brunelleschi.

Parole chiave

Brunelleschi, Rotonda degli Angeli, Monastero camaldolese degli Angeli

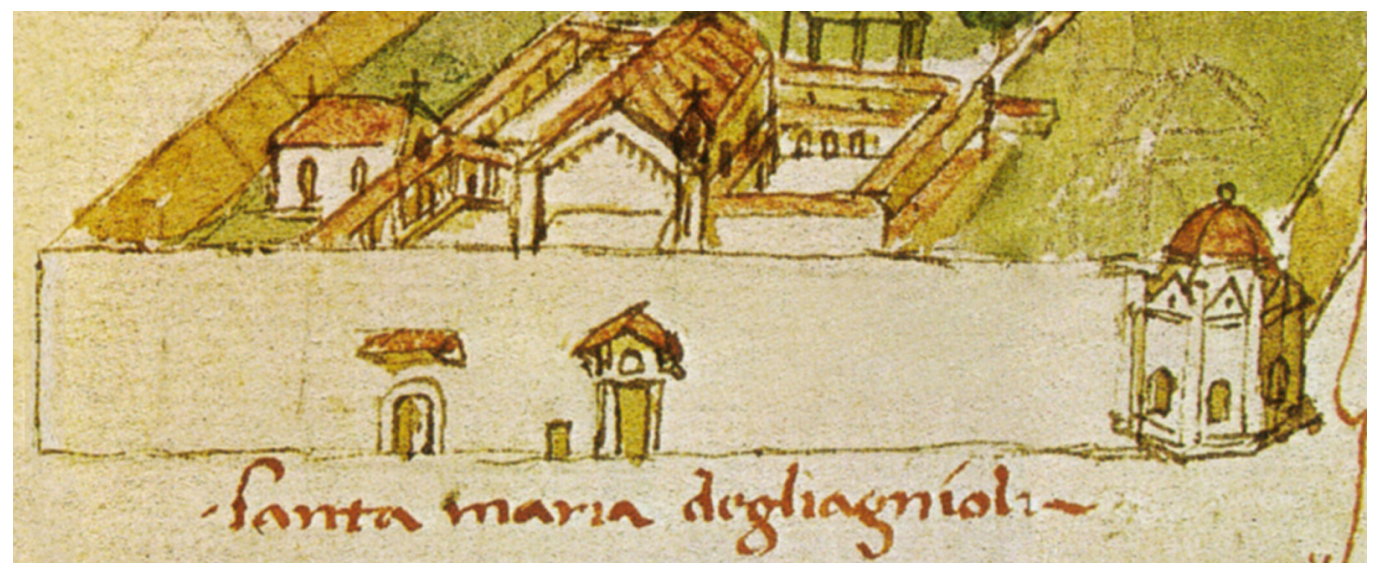




\section{Monastero camaldolese degli Angeli}

La Rotonda degli Angeli in origine faceva parte dell'antico Convento dei monaci camaldolesi di S. Romualdo; questi, giunti a Firenze nel 1295, si insediarono in una località chiamata Cafaggiolo, allora fuori dalle mura cittadine, dando così vita ad un primo cenobio [I].

La comunità in poco tempo accrebbe, nonostante la clausura regola dell'Ordine [2]. Alle numerose vocazioni corrisposero frequenti donazioni che contribuirono allo sviluppo del complesso [3] che ben presto divenne il centro di un'intensa attività religiosa, artistica e culturale [4].

Nella prima metà del $X V$ secolo un notevole impulso si ebbe grazie al priore Ambrogio Traversari che strinse contatti con eminenti personaggi come, ad esempio, Cosimo il Vecchio [5]: nel monastero si svolgevano le lezioni di latino e greco alle quali partecipò, tra gli altri, Lorenzo il Magnifico.

Nel XVI secolo il monastero degli Angeli visse un momento di intensa attività artistica ed edilizia: nel I534 Ridolfo del Ghirlandaio dipinge nel refettorio un'Ultima Cena; del I570 è il primo Chiostro di Bartolomeo Ammannati e Matteo Nigetti, che nel I62I ne realizzerà un secondo; il terzo, il più grande, del I647, è di Gherardo Silvani [6] (figg. I -4).

Altri lavori si susseguono nei secoli XVII e XVIII: nel I 676 la chiesa viene trasformata in un misurato barocco fiorentino. Operano nel complesso artisti quali Allori, Poccetti e Gherardini. Nel Settecento inizia una decadenza che porterà nel 1786 alla chiusura del Convento per mancanza di monaci. In epoca napoleonica nel 1808 il monastero viene soppresso; l'intero complesso passò di pertinenza all'attiguo Ospedale di S. Maria Nuova. Tale proprietà, eccetto una piccola porzione acquisita dalla Compagnia di S. Antonio Abate, venne confermata dopo l'Unità d'Italia.

Fig. I. II Convento camaldolese degli Angeli in una incisione del XVIII secolo conservata nella Biblioteca Classense di Ravenna. Sono ben visibil i tre chiostri e a sinistra i resti della Rotonda.

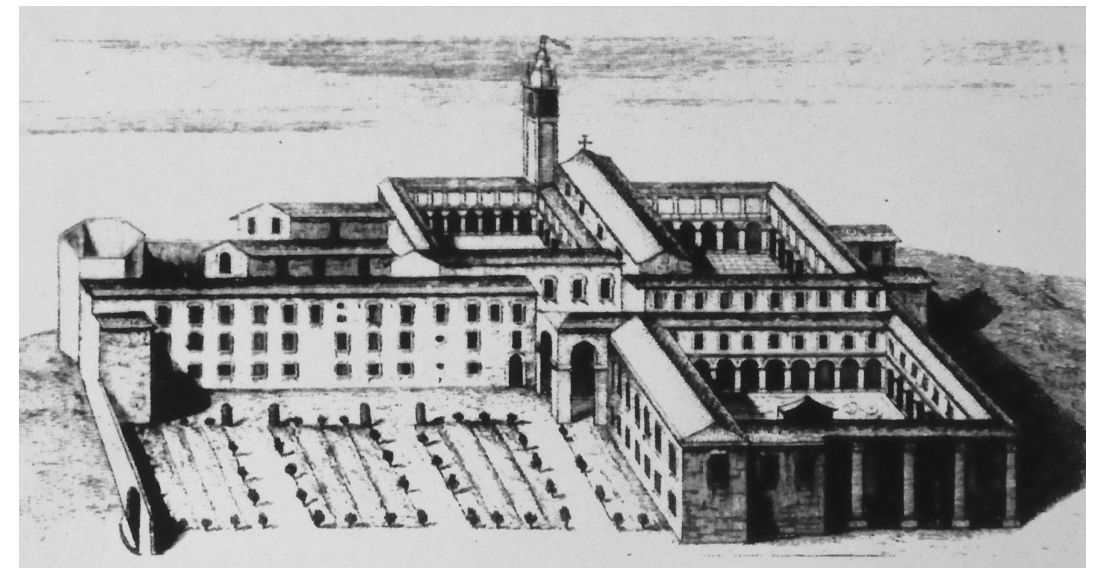

\section{II contesto urbano}

La Rotonda degli Angeli si trova sull'angolo tra le attuali via degli Alfani e via del Castellaccio (fig. 12); il toponimo potrebbe scaturire da Campaccio [7], oppure derivare dai ruderi di una torre ghibellina, molto frequenti nella Firenze medievale [8].

Alla metà del XIV secolo, via degli Alfani, dopo l'insediamento dei monaci camaldolesi, venne chiamata via degli Agnoli. Questa, all'altezza di via della Pergola, sul Canto alla Catena [9], prendeva il nome di via del Tiratoio degli Agnoli in quanto su quel crocevia era ubicato un 'tiratoio' dell'Arte della Lana. Di fronte a questo vi era l'Oratorio della SS. Annunziata detto, dopo il 1370 , delle Orbatelle [10]. La via del Tiratoio degli Agnoli terminava in angolo con borgo Pinti nel Canto di Montiloro, vicino alla chiesa di S. Maria di Candeli, risalente al I250 [I I] (figg. 2, 3). 


\section{Testamento degli Scolari: le premesse per il progetto brunelleschiano}

Intorno al I 433-I 434 i cugini Andrea e Matteo Scolari [ I 2] fanno testamento a favore del fratello di quest'ultimo, Pippo Spano (capitano al servizio del re Sigismondo di Ungheria) con l'obbligo di far edificare due conventi camaldolesi nel territorio fiorentino. Alla morte del condottiero le responsabilità passarono ai Consoli di Calimala [ I3] (l'Arte dei Mercanti); questi ritenuto insufficiente il lascito per la realizzazione di due siti [ 14], destinarono i fondi, ben 5000 fiorini d'oro (forse dietro suggerimento del priore Traversari) alla costruzione di un Oratorio dedicato alla Madonna da realizzarsi nelle vicinanze dell'esistente Convento degli Angeli.

I Consoli affidano a Brunelleschi l'incarico di realizzare l'edificio: i lavori partono celermente già nel I 434, ma si interruppero ben presto nel 1437.

Un esame accurato dell'atto notarile del 1434 , in particolare per ciò che concerne i riferimenti toponomastici, ci ha permesso di avanzare alcune ipotesi su come si presentava la zona intorno al monastero camaldolese all'epoca dell'intervento (figg. 2, 3).

Del testamento [15] si sono utilizzate due trascrizioni sostanzialmente concordi che non si contraddicono e si completano a vicenda: quelle del Savelli 1992 e del Saalman 1993.
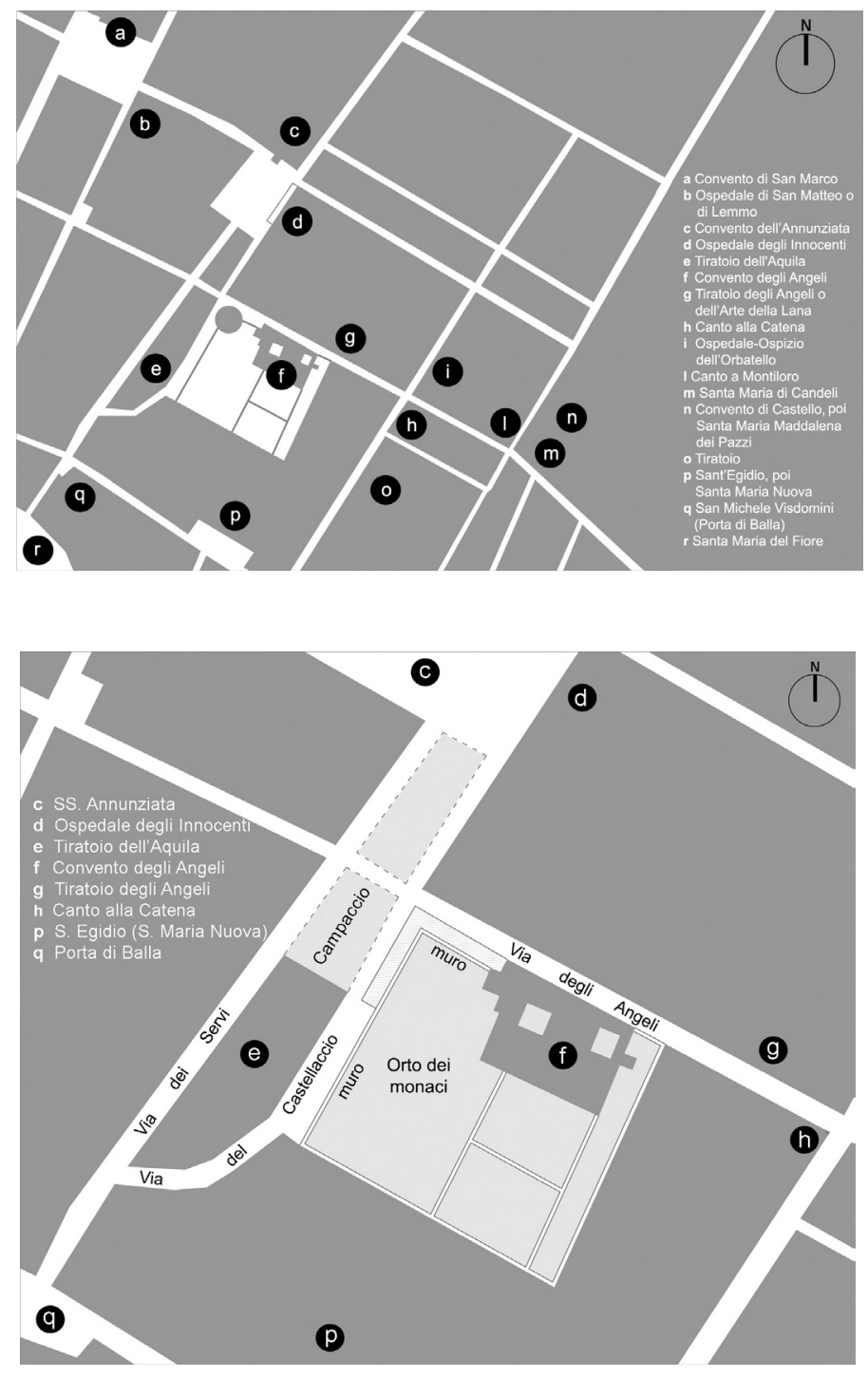
| passi riportati riguardano localizzazione e misure dellintervento. || documento recita: "il predetto oratorio [...] da edificarsi nuovo ad onere del Comune e dell'Arte predetta vicino o meglio nelle vicinanze del monastero degli eremiti predetti rispetto al quale è necessario si ponga nel giusto modo nella esistente via del comune vicino all'orto o meglio muro dell'orto del monastero predetto nel luogo detto il Campaccio fino all'angolo [...] di detto orto verso la chiesa di Santa Maria de' Servi fino al tiratoio dell'Arte predetta e signor Palla Strozzi [...] di edificare e far costruire sopra o meglio vicino alla predetta via dal muro [...] dell'orto degli eremiti predetti per latitudine verso il Campaccio fino alle mura del comune per la misura data totale o parziale di braccia II 3/4 [...] e per longitudine dal sopradetto angolo e muro dell'orto verso la via per la quale si va al monastero predetto per braccia 70 [...] verso il tiratoio dell'Arte dei Mercanti e signor Palla Strozzi e dal detto capo e luogo verso il detto Campaccio dalla parte opposta alla via dei Servi verso Occidente braccia dodici [...]. È chiaro che la costruzione era prevista non addossata al convento e non completamente nella proprietà dei monaci, ma in adiacenza al muro dell'orto che si estendeva ad ovest del monastero nell'angolo tra le attuali via degli Alfani e via del Castellaccio. Quest'ultima è forse quella via del Comune cui si fa riferimento nell'atto del I434:"è necessario si ponga nel giusto modo nella esistente via del comune". Questa strada, infatti, nel primo tratto ha mantenuto nome e percorso sostanzialmente identico al tracciato del XV secolo [16] che dirigeva verso Fiesole (le attuali via de' Fibbiai e via Gino Capponi) [17]. L'altro riferimento è: "vicino all'orto o meglio muro dell'orto del monastero predetto nel luogo detto il Campaccio". Quest'ultima frase farebbe pensare ad uno spazio ancora libero prospiciente il muro di cinta del convento che la costruenda Rotonda avrebbe potuto occupare [18].

Fig. 4. Particolare della pianta della Città di Firenze di Stefano Bonsignori del 1584 con le indicazion dei luoghi notevoli.

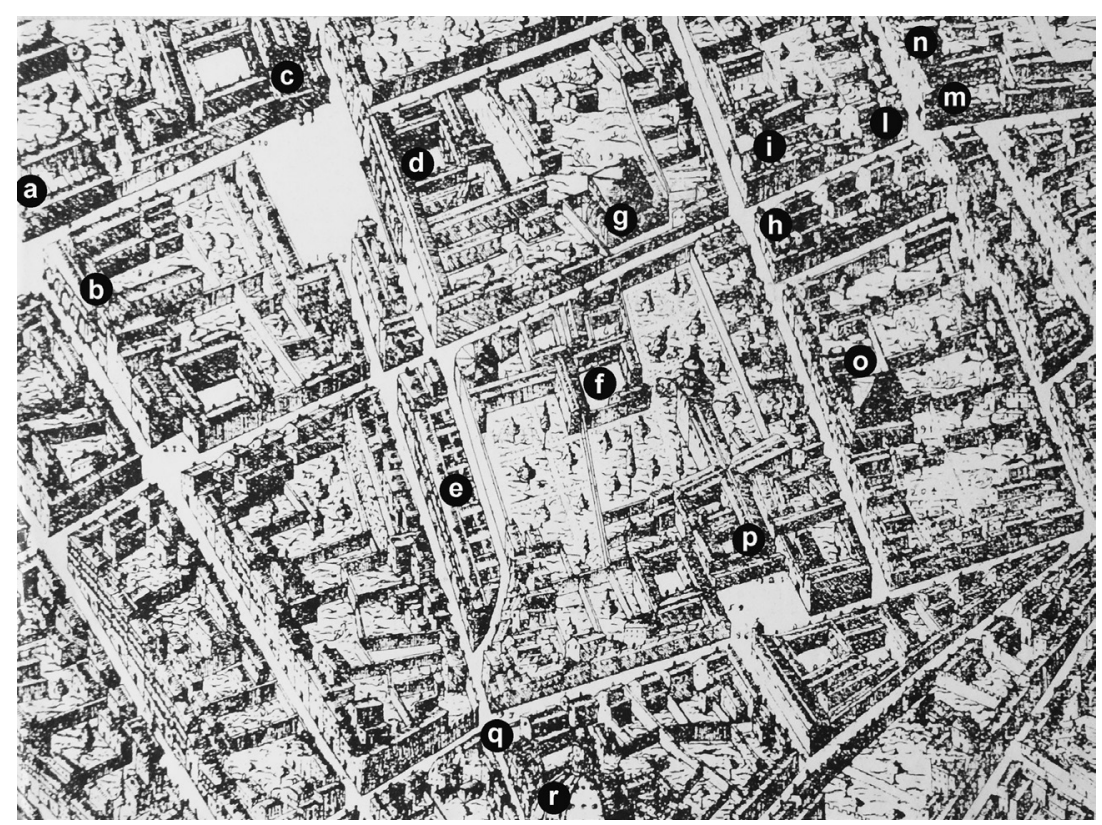

Abbiamo inserito sulla nostra ipotesi planimetrica le misure del documento del I434 (fig. 5). Punto base per i dati mensori è sicuramente l'angolo del muro di cinta dell'orto del convento, prospiciente via del Castellaccio, verso la SS. Annunziata. La misura di 70 braccia (m 40,85), presa da questo punto si riferiva alla lunghezza della recinzione dell'orto, arretrata rispetto al filo stradale di via degli Angeli, sino ai locali trecenteschi annessi alla sacrestia della chiesa. La larghezza di questa fascia di terreno è proprio di braccia II 3/4 (m 6,90) che risulta essere la misura contenuta nel documento che indica la porzione di terreno da occupare per longitudine dal muro dell'orto, che avrebbe permesso di rispettare e proseguire l'allineamento del convento con la strada. 
Fig. 5. Pianta schematica dell'area intorno al convento con le indicazioni delle misure in braccia fiorentine (m. 0,5836) contenute nel testamento degli Scolari del I 434.
Fig. 6. Pianta schematica dell'area intorno al convento con le ipotesi d ubicazione del/i portico/i.
La stessa misura di 70 braccia corrisponde alla lunghezza del muro di cinta su via del Castellaccio dall'angolo di base sino al probabile allineamento con il tiratoio dell'Arte dei Mercanti e di Nofri di Palla Strozzi. La larghezza di quest'altra fascia di terreno da occupare è data in braccia 12 (m. 7,00), in modo da allinearsi con il tratto superiore di via dell'attuale via de' Fibbiai, nonché con il fronte dell'Ospedale degli Innocenti [19] (figg. 2, 3).

Ne scaturisce una zona edificabile su terreno pubblico a forma di "L" capovolta, le cui dimensioni sono: lati esterni 82 braccia (m 47,85); lati interni 70 braccia (m 40,85) e spessore compreso tra braccia I| 3/4 e 12 (m 6,85 - 7,00).
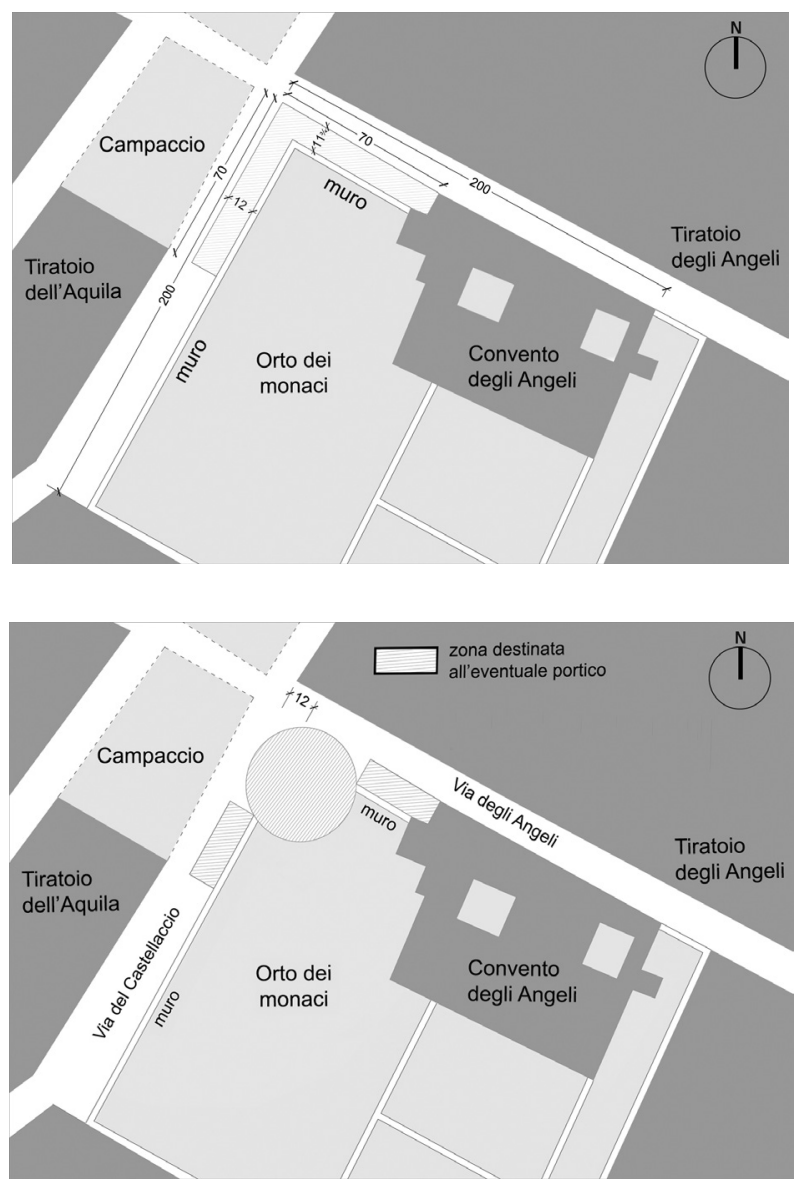

Se dal nuovo angolo (verso la SS. Annunziata) così ottenuto misuriamo "tanto di latitudine che di longitudine 200 (braccia)" ovvero I 16,72 metri, in direzione di via degli Angeli arriviamo giusto allo spigolo sud-est del convento, mentre in direzione di via del Castellaccio si arriva all'incirca al punto dove la strada curva per immettersi in via dei Servi. Duecento braccia erano, quindi, la misura dei lati della proprietà dei monaci prospicienti le strade comunali. Con questi limiti i camaldolesi potevano occupare "tanto per la longitudine che per la latitudine $[. .$.$] tanto terreno e prato necessario a colonne e scale stanti nel detto portico e$ edificio e da entrambe le parti delle colonne stesse"; quest'ultima frase ci fa pensare che, stando al testamento, era prevista la realizzazione oltre all'Oratorio di uno o più porticati su via degli Angeli e/o su via del Castellaccio da realizzarsi in un secondo momento: [...] e sia da procurarsi altra licenza e da farsi altra deliberazione poiché il luogo predetto o meglio portico da edificarsi e da costruirsi sopra detta via rimanga aperto nel modo e nella forma della pubblica costruzione esistente sopra la piazza di San Marco davanti all'ospedale di Lemmo in modo che sia libero e sempre aperto e chiunque possa avere adito e uscita dal predetto oratorio" [20]. 
Per qualche motivo a noi sconosciuto all'atto di conferire al Brunelleschi l'incarico dell'intervento, fu data priorità all'esecuzione dell'oratorio; la realizzazione del porticato (o dei porticati) lungo le pubbliche vie fu presumibilmente accantonata (fig. 6).

\section{Brunelleschi e la Rotonda}

Vuole la tradizione che per l'Oratorio degli Scolari Brunelleschi approntasse alcuni disegni e un modello, poi perduti. Ne parlano le fonti, il Codice Rustici innanzi tutto [2I] (fig. 7) e gli Autori più antichi a cominciare dal Vasari "Fece ancora il modello del bizzarrissimo tempio degl'Angeli" [22] e altri ancora successivamente [23].

Fig. 7. Particolare della Rotonda e del Convento degli Angeli tratto del "Codice Rustici" di Marco di Bartolomeo Rustici, metà XV secolo circa,

conservato nel Seminario Arcivescovile Maggiore di Firenze.

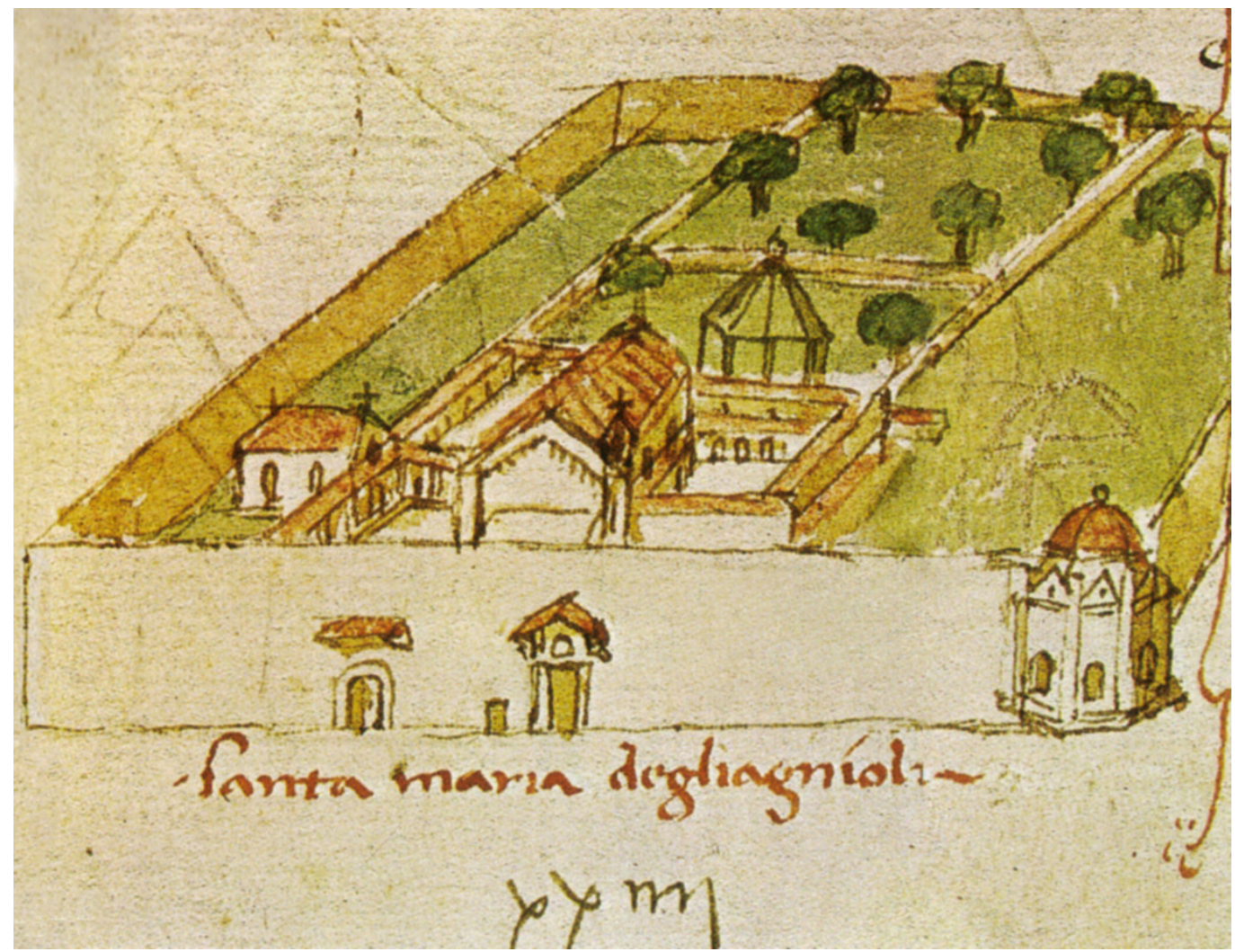

Rodolfo Sabatini, l'architetto che nel 1932 restaurerà la Rotonda, per meglio visualizzare l'intervento alla committenza (fig. 8), riterrà opportuno presentare un modellino in gesso (fig. 9) della metà sezionata dell'edificio [24].

II cantiere dell'Oratorio partì subito nel |434, ma si interruppe presto nel |437, quando la costruzione era giunta all'altezza di "oltre nove braccia" [25]: Antonio Manetti, biografo del Brunelleschi, scriveva "il tempio degli Agnoli [...] preparato e fatto insino a dove oggi si truova, [...] circa tutto intorno quanto alzano e pilastri delle cappelle" [26]. Motivo di questa sospensione fu la guerra di Firenze contro Lucca [27]. Altre concause vanno forse ricercate nelle lotte interne conseguenti al ritorno dall'esilio di Cosimo il Vecchio o la morte del priore Ambrogio Traversari. Nonostante l'ammirazione e l'interesse dei contemporanei per la rivoluzionaria architettura [28], questa rimase per molti secoli nel più completo abbandono [29] (fig. 10). 


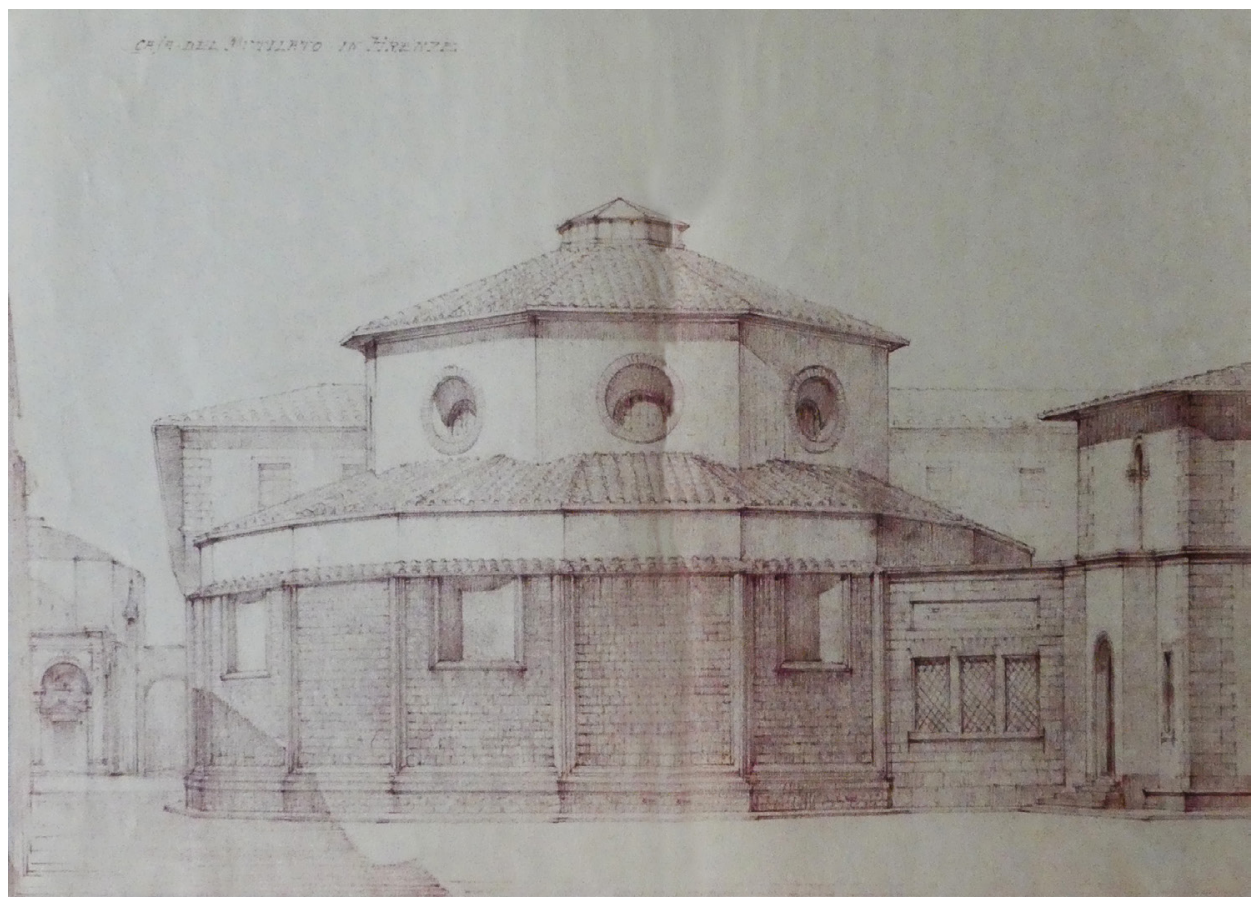

Fig. 9. Modellino in gesso di Rodolfo Sabatini del

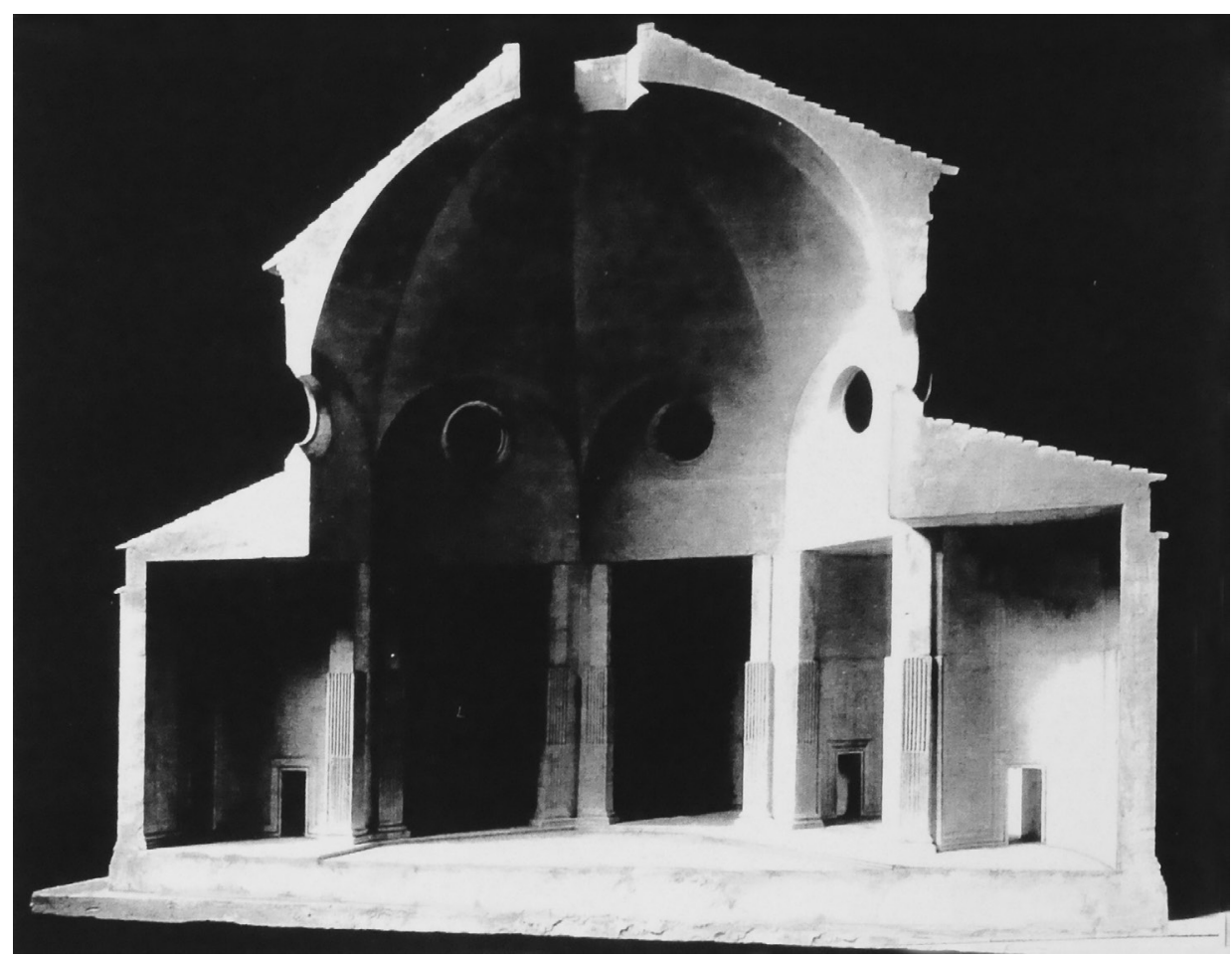


Fig. 10. Foto del 1930 circa della Rotonda del Brunelleschi nell'angolo tra via degli Alfani e via lavori di rifacimento.

Fig. | |. Giuliano da Sangallo, Codice Barberiniano Latino Vaticano, Foglio 5 verso, particolare con a pianta e una sezione della Rotonda degli Angeli. del Castellaccio prima dei
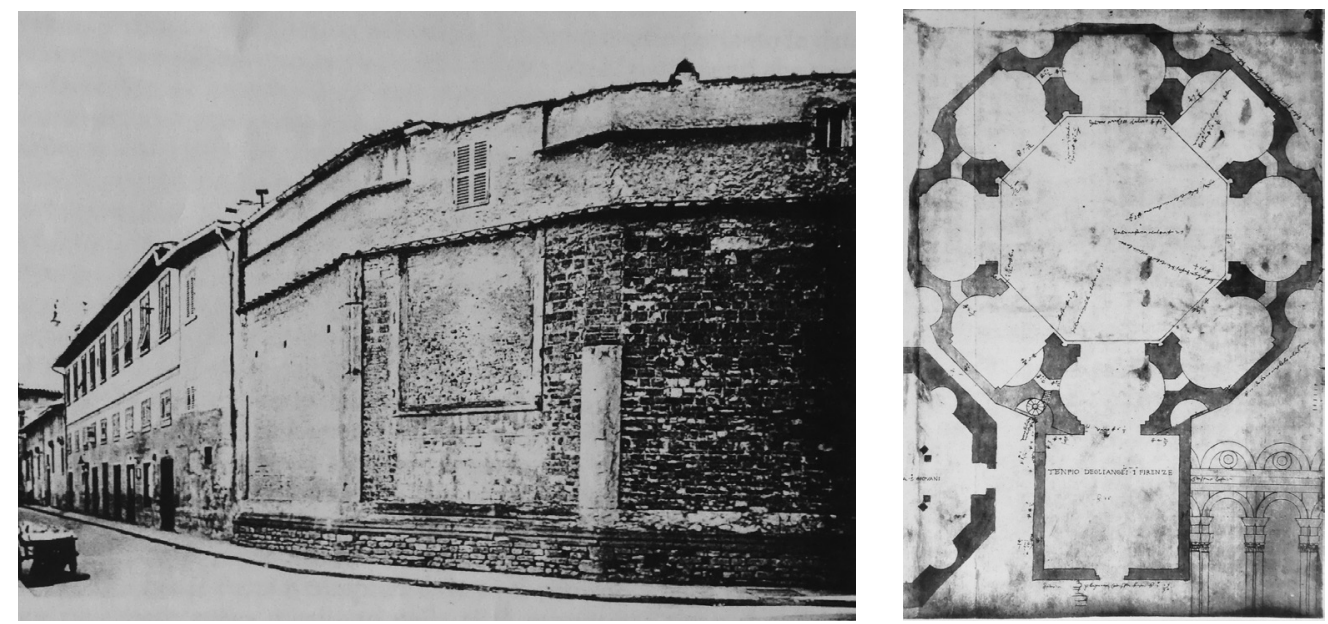

\section{Conclusioni}

Non sappiamo come Brunelleschi intendesse completare la Rotonda; com'è noto l'artista non manifestava mai apertamente e per intero i propri intenti progettuali. I disegni e il modello prodotti non contenevano molti particolari e tante erano le indicazioni che Filippo si riservava di spiegare 'a voce' durante i lavori. II modello conservato nel Convento era semplice ed essenziale, forse non vi erano indicazioni né per l'entrata, né per il coro; questo spiegherebbe le diversità tra le due rappresentazioni interne più antiche del complesso: la prospettiva del Codice Ashburnaham e l'interno nel Codice Barberiniano [30] (fig. I I), risultato di personali interpretazioni di uno o di entrambi gli autori [3। ]. Al portico (o ai portici) Brunelleschi probabilmente non dedicò molte idee: sicuramente non lo pensò in asse con l'ingresso della Rotonda. Gli spazi disponibili ne avrebbero previsto la costruzione solo in adiacenza ai muri del Convento su via del Castellaccio o di via degli Angeli (via degli Alfani) [32].

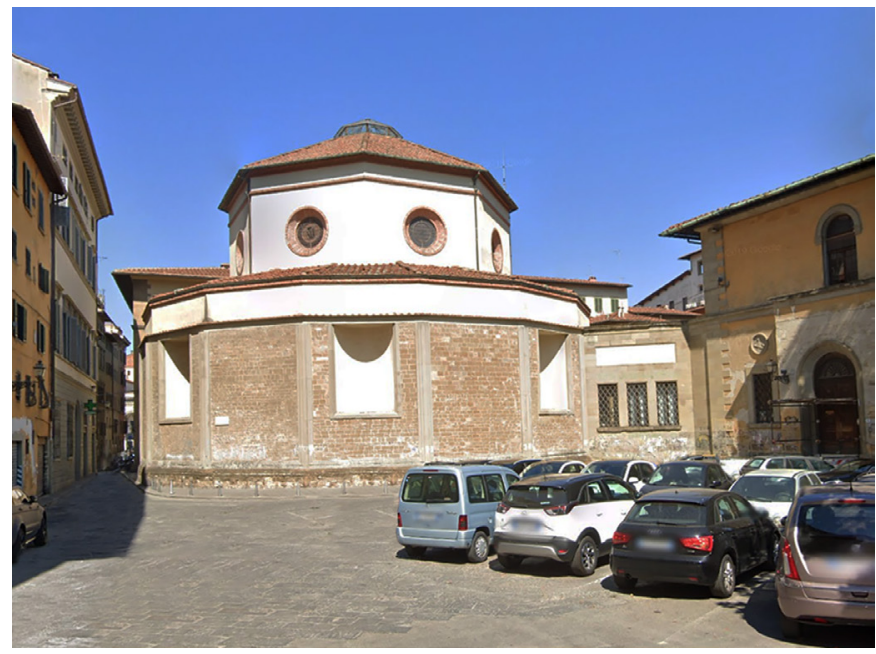

\section{Note}

[I] Le linee generali del più antico Convento sono ancora facilmente riconoscibili nella planimetria attuale [Savelli I983].

[2] La clausura viene abolita nella seconda metà del XV secolo.

[3] La misura delle ricchezze contenute nel monastero è data dall'episodio del I 378, quando, in occasione del famoso Tumulto dei Ciompi, il convento viene saccheggiato, in quanto molti facoltosi cittadini avevano qui depositato i loro averi. 
[4] II monastero camaldolese divenne il centro di una prestigiosa e fiorente scuola di miniatori che produceva Codici unici, preziosi e stupendi; qui si formarono artisti quali Lorenzo Monaco che nel convento realizzò una "Incoronazione della Vergine". All'interno del complesso erano custodite importanti opere d'Arte, quali un'urna in bronzo del Ghiberti, un "Giudizio Universale" del Beato Angelico, due "Crocifissioni" di Andrea del Castagno, per citarne alcune.

[5] Cosimo de' Medici aveva il patrocinio di un altare nel Monastero [Romby 1979, p. I0]. Tra i frequentatori abituali de Convento troviamo Leonardo Bruni, Poggio Bracciolini e Carlo Marsuppini e Marsilio Ficino.

[6] Dei chiostri del Convento degli Angeli ne parla Savelli [Savelli 1983, pp. 19-22].

[7] Questo termine si ritrova più volte nei documenti notarili del I433-34 inerenti l'Oratorio e il Monastero camaldolese.

[8] Su via del Castellaccio il Bargellini ipotizza: "Abbiamo già detto, nel parlare di Via degli Alfani e di Piazza Brunelleschi, come nel 'cafaggio' vicino esistesse un Tiratoio del Castellaccio, forse chiamato così per qualche torre ghibellina, diruta al tempo delle guerre civili. Quello di Castellaccio dovette essere un nome molto antico, che probabilmente passò dalla diruta torre alla incompiuta Rotonda" [Bargellini-Guarnieri 1977, p. 214]. || Saalman [Saalman 1993, p. 386], sostiene che il termine Campaccio non indichi un luogo preciso, ma vada inteso genericamente e si riferisce a terreni liberi edificabili.

[9] L'angolo tra via degli Alfani e via della Pergola era nominato Canto alla Catena per gli stemmi della famiglia Alberti lì posti, quattro catene congiunte al centro da un anello [Bargellini 1977, p. 45].

[ I0] Sin dal 1370 la famiglia degli Alberti ebbe il patronato dell'ospizio delle Orbatelle; dopo il loro esilio il complesso passò all'Arte della Lana [Bargellini 1977, p. 44].

[I I] Al Canto di Montiloro la Compagnia dell'Assunta (Monti d'oro dallo stemma della stessa) aveva un tabernacolo; accanto alla chiesa di Santa Maria di Candeli vi era un antico convento di monache agostiniane, ora adibito a Caserma dei C.C. [Bargellini 1977, pp. 44-47]

[12] Notizie più dettagliate sulle vicende del testamento si trovano in: Saalman 1993, pp. 384-396; Savelli 1992, pp. I 3 ss.; Battisti 1977, pp. 253 ss.; Miarelli Mariani 1974, p. 47. Un iter esaustivo della vicenda testamentaria e dei personaggi ad essa legati si trova in: Linacher 1918-19, 1919-20. Nel primo atto datato I5 marzo |433 si legge: "Nell'oratorio 'e nei suoi edifici' dovranno essere ben visibili, «dipinte e scolpite», le armi e le insegne della detta Arte (di Calimala) e della famiglia Scolari" [Savelli I992, p. 39].

[13] Una prima richiesta in tal senso era stata inoltrata da Pippo Spano a Papa Martino V [Saalman 1993, p. 384].

[14] Nei primi intenti dei donatori si prevedeva la costruzione di due monasteri nelle località di Tizzano e Vicchiomaggio [Savelli 1992, p. I3].

[15] Le trascrizioni del documento originale, conservato presso l'Archivio di Stato di Firenze, C.S. Diplomatico, Fondo S. Maria degli Angeli, del 16 aprile 1434 sono in: Savelli 1992, pp. 40-4I; Bass 1980, pp.477-484; da quest'ultima Saalman 1993, pp. 452453; Savelli 1992, pp. 4I-43.

[16] Era questa una porta delle mura del XI secolo, dove attualmente è l'incrocio tra via de' Pucci, via Bufalini e via dei Servi: quest'ultima strada fu creata dopo il 1256 congiungendo in linea retta la porta di Balla con la chiesa della SS. Annunziata. Ciò non diminui l'importanza di via del Castellaccio se il Brunelleschi vi allinea il portico degli Innocenti. La porta deve il toponimo alla presenza nella zona dei tiratoi dell'Arte della Lana e all'intenso traffico di balle di lana che qui si sviluppava [Fanelli I973, p. 25]. La presenza in questa zona di numerosi tiratoi si spiega considerando l'antico corso del Mugnone, lungo via del Castellaccio e della seconda cerchia di mura [Pietramellara 1978, p. 42]

[17] Anticamente via Gino Capponi ebbe nome via Orto dei Servi e via San Sebastiano.

[ 18] Saalman [Saalman 1993, pp. 386-39I] identifica il luogo detto Campaccio con l'area non ancora edificata compresa tra la via dei Servi, via degli Alfani e via del Castellaccio.

[19] La Rotonda sarebbe venuta a trovarsi in contatto visivo, se non proprio allineata, con il Portico degli Innocenti.

[20] Savelli [Savelli 1992, p. 42]. II portico a cui si fa riferimento è quello esterno dell'ex ospedale di Lemmo o di San Matteo (l'attuale Accademia) in piazza San Marco (figg. 2-4).

[2I] "Codice Rustici" di Marco di Bartolomeo Rustici, metà XV sec. ca., conservato nel Seminario Arcivescovile Maggiore di Firenze [Acidini-Gurrieri, 2018]

[22] Dalle "Vite del Vasari ..." (Ed. giuntina I 568 - ristampa 1993, p. 345). Lo stesso Vasari parla di un disegno del Brunelleschi in suo possesso: "Le carte della pianta e del finimento del quale tempio a otto facce, di mano di Filippo, è nel nostro libro, con altri disegni del medesimo".

[23] Di un disegno di Brunelleschi conservato nel Convento parlano numerosi Autori a partire dal XVII secolo [Miarelli Mariani 1975, pp. 35-48].

[24] I| committente era l'Associazione Nazionale Militari Invalidi di Guerra. II Sabatini presentò ai dirigenti dell'epoca un modellino in gesso che si conservò nei locali dell'Associazione sino al 1966, quando, dopo la disastrosa alluvione di novembre, andò perduto.

[25] Linacher 1920, p. 10

[26] Manetti 1976, p. 105.

[27] Vasari, Le Vite, p. 345: “('Oratorio) rimase imperfetto e nella maniera che oggi si vede, per avere i Fiorentini spesi i danari (...) nella guerra che già ebbero co' Lucchesi'.

[28] Leon Battista Alberti, nel VI Libro, parlando di Brunelleschi e della Rotonda aveva scritto: "mescolando elementi di pari proporzioni, linee rette con linee curve, luci con ombre... (egli cercò e riuscì di) ... ricavare, come da una congiunzione tra elementi maschili e femminili, qualcosa di nuovo". 
[29] Nel 1503 il perimetro della Rotonda fu coperto da un tetto che crollò nel I63|. Nel I 563 Cosimo I avrebbe voluto instituire nel complesso la sede dell'Accademia del Disegno, ma i monaci si opposero a tale soluzione dando così iniziò al lento e inesorabile degrado dell'edificio brunelleschiano.

[30] Huelsen 1910, Fg. $15 \mathrm{~V}$.

[3।] Bruschi 1972, p. I I4: qui in appendice una "Ipotesi di ricostruzione grafica dell'alzato della Rotonda degli Angeli".

[32] Si veda: Scalzo 2001 , pp. 853-86I

\section{Riferimenti bibliografici}

Acidini Cristina, Gurrieri Elena (2018). Firenze 1450-Firenze oggi. I luoghi di Marco Rustici orafo del Rinascimento. Firenze: Leo S. Olschki.

Bargellini Piero, Guarnieri Enrico (1977). Le strade di Firenze. Firenze: Bonechi.

Bass Geraldine (1980). Two documents on the Tempio degli Angeli. In De Angelis d'Ossat Guglielmo et al. (a cura di). Filippo Brunelleschi: la sua opera e il suo tempo. Firenze, 16-22 ottobre 1977. Firenze: Centro Di II, pp. 477-484.

Battisti Eugenio. (1977). Filippo Brunelleschi. Milano: Electa.

Bruschi Arnaldo (1972). Considerazioni sulla "maniera matura" del Brunelleschi. In Palladio, nn I-IV, gen.-dic., pp. 89- 126.

Fanelli Giovanni (1973). Firenze, architettura e città. Firenze:Vallecchi.

Farulli Gregorio (17/0). Istoria cronologica del nobile e antico Monastero degli Angioli di Firenze. Firenze.

Huelsen Christian (1910). Il libro di Giuliano da Sangallo - Codice Barberiniano Latino. Torino: Lipsia.

Linacher Arturo (1920). II "Tempio degli Scolari", estratto dagli Atti della Società Colombaria di Firenze (anni 1918-19 e 1919-20). Firenze: L'Arte della Stampa.

Manetti Antonio (1976). Vita di Filippo Brunelleschi. Milano: II Polifilo.

Miarelli Mariani Giuseppe (1974). II tempio fiorentino degli Scolari - Ipotesi e notizie sopra una irrealizzata opera brunelleschiana. In Palladio, nn. I.IV, gennaio-dicembre, pp.45-74.

Miarelli Mariani Giuseppe (1975). I disegni per la Rotonda degli Angioli: elementi per la ricomposizione del progetto di Michelangelo. In Antichità Viva, XIV, 1975, 2, pp. 35-48.

Millon Henry A. (1994). I modelli architettonici nel Rinascimento, in Rinascimento da Brunelleschi a Michelangelo - La rappresentazione dell'architettura, Bompiani, Milano.

Pietramellara Carla (1978). Alcuni aspetti dell'arte tarda del Brunelleschi, in Antichità Viva, XVII, I978, I, pp. 40-5 I.

Romby Giuseppina Carla (1979). Per costruire ai tempi del Brunelleschi - modi, norme e consuetudini del quattrocento fiorentino Firenze: Clusf.

Saalman Howard (1993). Filippo Brunelleschi.The Buildings, Zwemmer, London.

Savelli Divo (1983). Il Convento di S.Maria degli Angeli a Firenze. Firenze:Tornatrè

Savelli Divo (1992). La Rotonda del Brunelleschi - Storia e documenti. Firenze: Esuvia, .

Scalzo Marcello ( 1995). La ricostruzione della Rotonda del Brunelleschi tra memoria e invenzione. In AAVV. II disegno luogo della memoria. Atti del Convegno. Alinea: Firenze, pp. 2 I 5-234.

Scalzo Marcello (1996). Un "disegno-documento" da Giuliano da Sangallo ai nostri giorni: la pianta della Rotonda degli Angeli, Tesi di Dottorato, Università degli Studi di Firenze.

Scalzo Marcello (200 I). II portico della Rotonda degli Angeli di Brunelleschi: un'ipotesi. In Coppo S., Davico P. (a cura di). II disegno dei portici. Il disegno della città.Torino:Celid.

Vasari Giorgio (1993). Le Vite dei più eccellenti pittori, scultori e architetti (dall'edizione giuntina del I568). Roma: Newton.

\section{Autore}

Marcello Scalzo, Università degli Studi di Firenze, marcello.scalzo@unife.it

Per citare questo capitolo: Scalzo Marcello (2020). II Monastero camaldolese degli Angeli e la Rotonda di Brunelleschi: possibili connessioni/The Monastero Camaldolese degli Angeli and the Rotonda of Brunelleschi: possible connections. In Arena A., Arena M., Brandolino R.G., Colistra D. Ginex G., Mediati D., Nucifora S., Raffa P. (a cura di). Connettere. Un disegno per annodare e tessere. Atti del $42^{\circ}$ Convegno Internazionale dei Docent delle Discipline della Rappresentazione/Connecting. Drawing for weaving relationships. Proceedings of the 42th International Conference of Representation Disciplines Teachers. Milano: FrancoAngeli, pp. 2674-2693. 


\section{The Monastero Camaldolese degli Angeli and the Rotonda of Brunelleschi: Possible Connections}

Marcello Scalzo

\section{Abstract}

Through the reading of the Testament drawn up by the members of the Scolari family, we hypothesize the location and shape of the Rotonda degli Angeli, a circular building built by Filippo Brunelleschi from | 434 to | 437 but still unfinished. We try to think about its location in the Florentine urban fabric dating back to the first decades of the fifteenth century, and how the architect (interpreting the testamentary on the spaces to be occupied) realizes the building not adjacent to the existing Convent, but far away, at the intersection of two important streets, in a very important position of the urban layout. It is also hypothesized the possible location of one or more porticoes, the construction of which was originally foreseen in the testamentary legacy. Furthermore, the existence of drawings and models originally made by Brunelleschi is investigated.

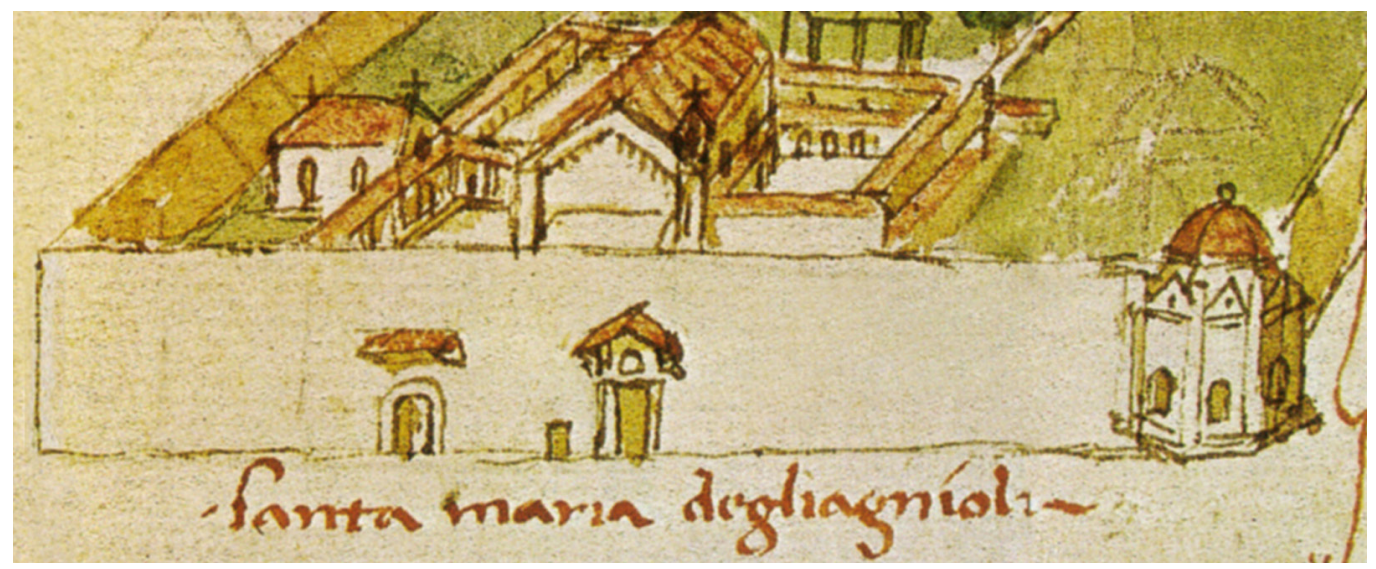




\section{The Monastero camaldolese degli Angeli}

The Rotonda degli Angeli was originally part of the ancient Convent of the Camaldolese monks of S. Romualdo; the monks arrived in Florence in 1295, settled in a place called Cafaggiolo, which was outside the city walls, and created a first 'cenobio' [I].

The community grew in a short time, although the monks had the rule of cloistered [2]. Many young monks entered the convent and rich citizens donated money that contributed to the development of the monastery [3] which became the center of an intense religious, artistic and cultural life [4].

In the first half of the fifteenth century the Convent has a remarkable development for the prior Ambrogio Traversari, he collaborated with important figures of Florence, for example, Cosimo il Vecchio [5]: in the monastery lessons of Latin and Greek were held in these also participated Lorenzo il Magnifico.

In the $16^{\text {th }}$ century the Monastero degli Angeli lived an important artistic and building activity: in 1534 Ridolfo del Ghirlandaio painted a Ultima Cena in the refectory; in 1570 it was the first Cloister by Bartolomeo Ammannati and Matteo Nigetti, who built a second one in I62 I; the third, the largest, in 1647, was by Gherardo Silvani (figs. I-4) [6].

Other works were carried out in the $17^{\text {th }}$ and $18^{\text {th }}$ centuries: in 1676 the church was transformed into Florentine Baroque. Other artists worked in the convent: Allori, Poccetti and Gherardini.

In the eighteenth century begins a decline that led in 1786 to the closure of the Convent for lack of monks. During the Napoleonic era in 1808 the monastery was suppressed; the entire monastery passed to the nearby Hospital of S. Maria Nuova. This property, except for some spaces purchased by the Compagnia di S. Antonio Abate, was confirmed after the unification of Italy.

Fig. I.The Camaldolese Convento degli Angeli in an engraving of the 18th century preserved in the Classense Library of Ravenna. The three cloisters are clearly visible and on the Rotonda. the Rotonda.

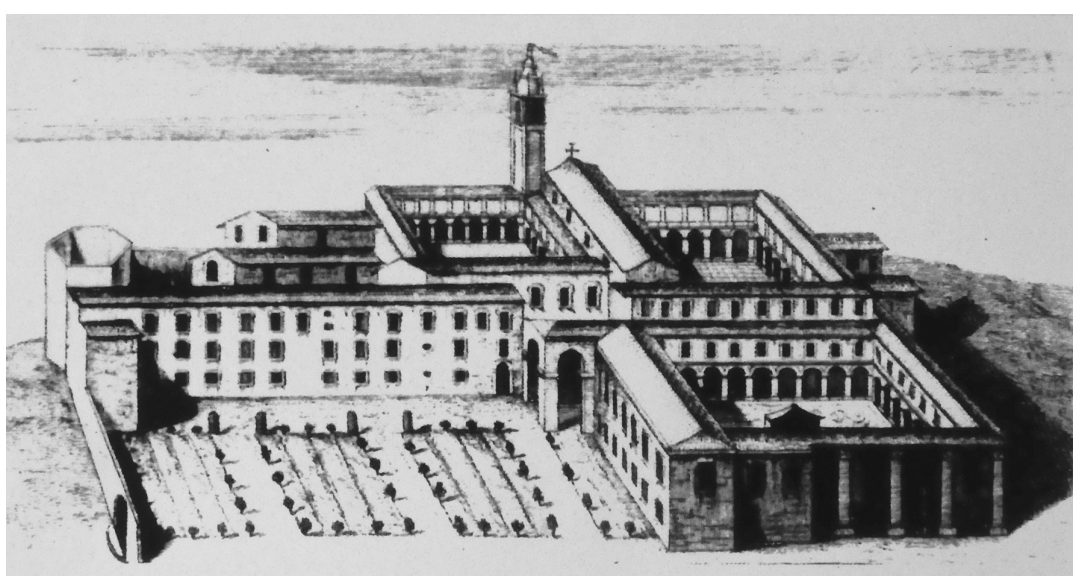

\section{The urban context}

The Rotonda degli Angeli is located on the corner of via degli Alfani and Via del Castellaccio (fig. I2); the toponym could derive from Campaccio [7], or from the ruins of a Ghibelline tower, very frequent in medieval Florence [8].

In the middle of the XIV century, via degli Alfani, after the settlement of the Camaldolese monks, was calledVia degli Agnoli. This street, at the corner ofVia della Pergola, on the Canto alla Catena [9], was called via delTiratoio degli Agnoli because on that crossroads there was a 'tiratoio' of the Arte della Lana. In front of it there was the Oratorio della SS. Annunziata called, after 1370, of the Orbatelle [I 0]. TheVia del Tiratoio degli Agnoli ended at the corner with the borgo Pinti in the Canto di Montiloro, near the church of S. Maria di Candeli, dating back to I250 (figg. 2-3) [I I]. 


\section{The Testament of the Scolari: the premises for Brunelleschi's project}

Around I 433-34 the cousins Andrea and Matteo Scolari [12] wrote a testament in favour of the latter's brother, Pippo Spano (captain in the service of King Sigismondo of Hungary) with the obligation to have two Camaldolese convents built in the territory of Florence. When Pippo Spano died the responsibility passed to the Consoli di Calimala [13] (the Arte dei Mercanti); they considered the legacy insufficient for the construction of two sites [I 4] and allocated the funds, 5000 gold florins (perhaps at the suggestion of PriorTraversari) to the construction of an Oratory for the Madonna to be built near the existing Convento degli Angeli.

The Consoli di Calimala entrusted Brunelleschi with the task of constructing the building: work began quickly as early as 1434 but was soon interrupted in 1437.

An examination of the notarial deed of 1434, as regards the references to the streets of Florence, highlights some hypotheses on what the area around the Camaldolese monastery looked like in 1434 (figs. 2, 3).

Two almost identical translations of the testament [15] have been used which do not contradict and complement each other: those of Savelli 1992 and Saalman 1993.
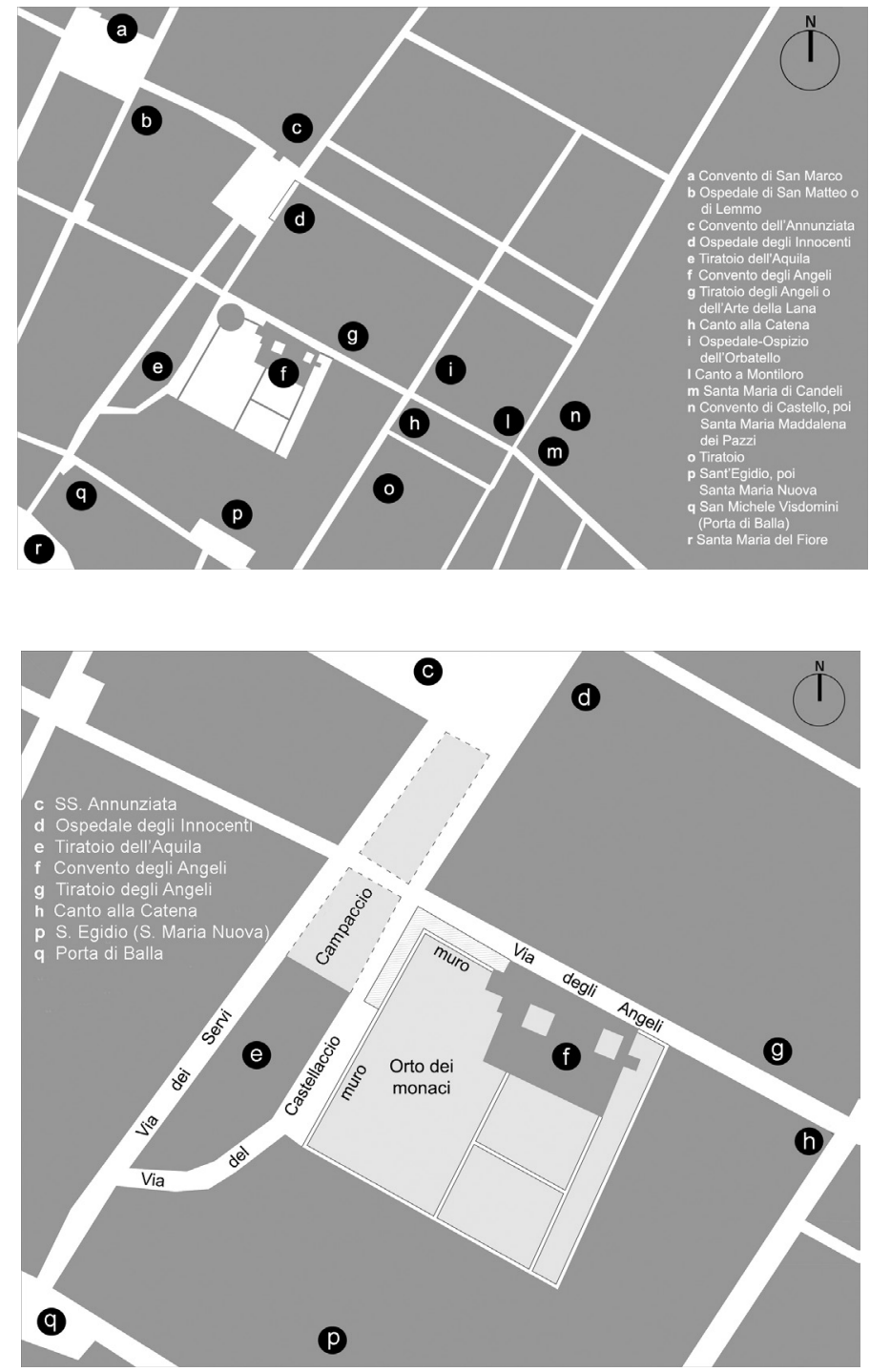
The reported parts examine the location and measures of the intervention. In the testament it is written:"il predetto oratorio [...] da edificarsi nuovo ad onere del Comune e dell'Arte predetta vicino o meglio nelle vicinanze del monastero degli eremiti predetti rispetto al quale è necessario si ponga nel giusto modo nella esistente via del comune vicino all'orto o meglio muro dell'orto del monastero predetto nel luogo detto il Campaccio fino all'angolo [...] di detto orto verso la chiesa di Santa Maria de' Servi fino al tiratoio dell'Arte predetta e signor Palla Strozzi [...] di edificare e far costruire sopra o meglio vicino alla predetta via dal muro [...] dell'orto degli eremiti predetti per latitudine verso il Campaccio fino alle mura del comune per la misura data totale o parziale di braccia || 3/4 [...] e per longitudine dal sopradetto angolo e muro dell'orto verso la via per la quale si va al monastero predetto per braccia $70[\ldots]$ verso il tiratoio dell'Arte dei Mercanti e signor Palla Strozzi e dal detto capo e luogo verso il detto Campaccio dalla parte opposta alla via dei Servi verso Occidente braccia dodici".

It is clear that the construction was planned not against the convent and not completely on the monks' property, but adjacent to the wall of the garden that extended to the west of the monastery at the corner between the present-day Via degli Alfani and Via del Castellaccio. The latter is perhaps that Via del Comune cited in the act of I434: "it is necessary to place oneself in the right way in the existing via del comune". This street, in fact, in the first stretch has kept its name and route substantially identical to the route of the fifteenth century [16] which directed towards Fiesole (the current Via de' Fibbiai and Via Gino Capponi) [17]. The other reference is: "vicino all'orto o meglio muro dell'orto del monastero predetto nel luogo detto il Campaccio". This last sentence would make one think of a space still free in front of the wall of the monastery that the Rotonda by Brunelleschi could occupy [18].

Fig. 4. Detail of the plan of Florence by Stefano Bonsignori of I 584 with the indications of the remarkable places.

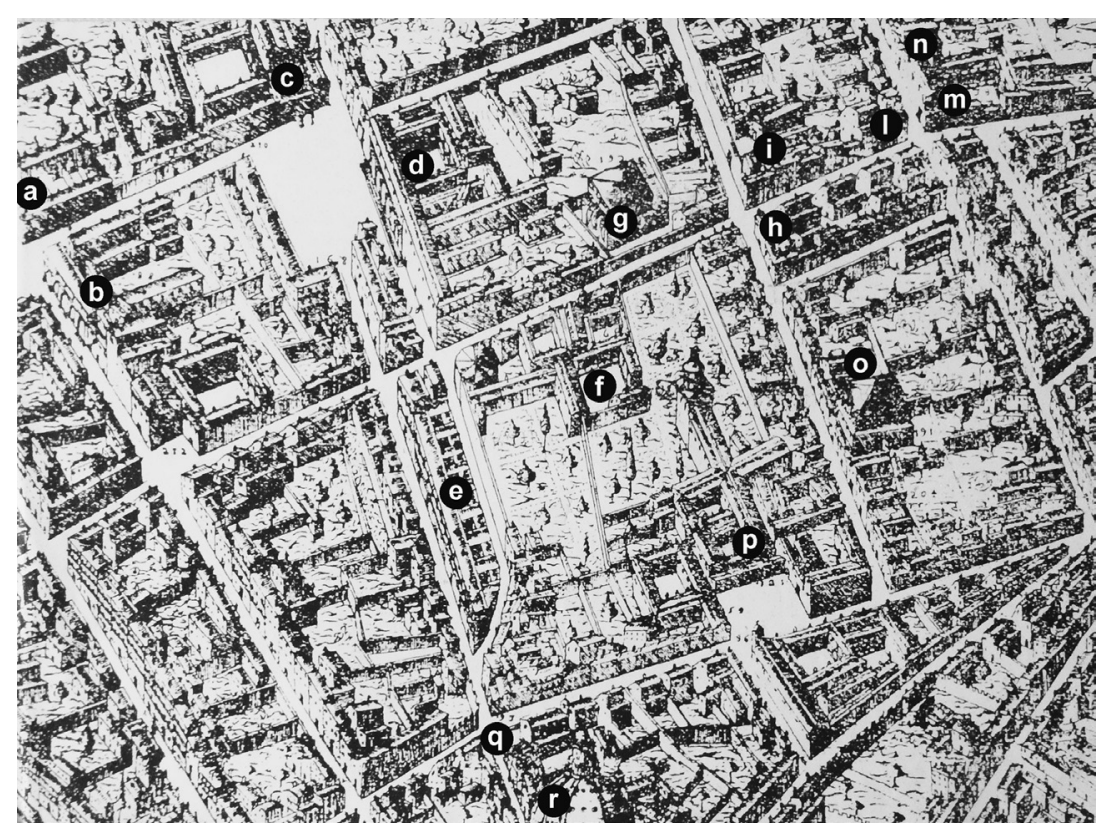

We have inserted on our hypothesis of the plan the measures of the document of I434 (fig. 5).

The base point for the measurements is certainly the corner of the boundary wall of the orto del convento, overlooking via del Castellaccio, towards the SS. Annunziata. The measure of 70 arms $(40.85 \mathrm{~m})$, taken from this point, referred to the length of the garden's fence, set back from the street line of via degli Angeli, up to the buildings built in the fourteenth century annexed to the sacristy of the church.The width of this strip of land is exactly II 3/4 arms $(6.90 \mathrm{~m})$ which is the measure contained in the document that indicates the portion of land to be occupied by longitude from the muro dell'orto, which would have allowed to respect and continue the alignment of the convent with the street. 
Fig. 5. Schematic map of the area around the convent with indications of the measurements in Florentine arms ( $\mathrm{m}$. 0.5836 ) contained in the Testament of the Scolari of 1434
Fig. 6. Schematic plan of the area around the convent with the hypothesis of the loca
of the portico(s).
The same measure of 70 arms corresponds to the length of the boundary wall on via del Castellaccio from the base angle to the probable alignment with the Arte dei Mercanti and Nofri by Palla Strozzi's tiratoio. The width of this other strip of land to be occupied by arms 12 (m. 7.00), to align with the upper section of the current Via de' Fibbiai, as well as with the front of the Ospedale degli Innocenti [19] (figs. 2, 3).

The result is a building area on public land with an inverted " $\mathrm{L}$ " shape, whose dimensions are: external sides 82 arms ( $m$ 47.85); internal sides 70 arms ( $m$ 40.85) and thickness between arms II $3 / 4$ and 12 (m $6.85-7.00)$.
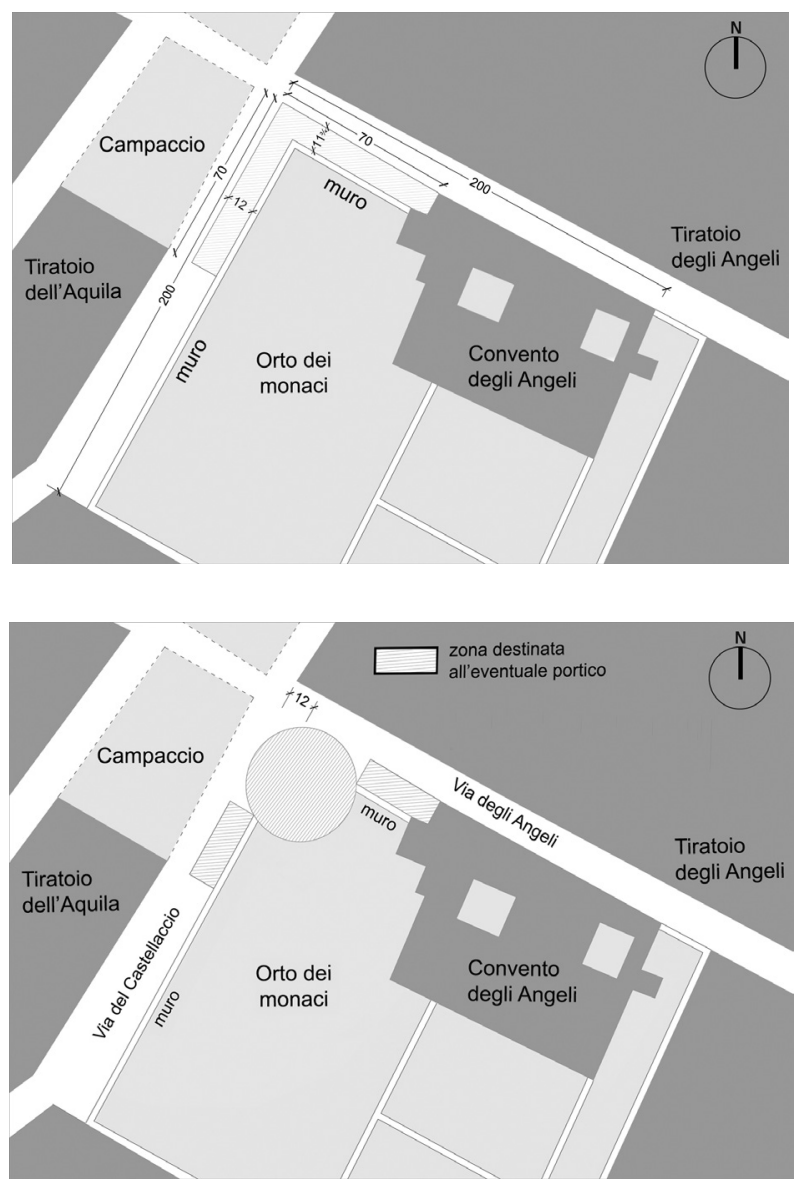

If from the new corner (towards the SS. Annunziata) so obtained we measure "tanto di latitudine che di longitudine 200 (braccia)" that is I 6.72 metres, in the direction of Via degli Angeli we arrive precisely at the south-east corner of the convent, while in the direction of Via del Castellaccio we arrive approximately at the point where the street curves to enter Via dei Servi. Two hundred arms were, therefore, the measure of the sides of the monks' property facing the municipal street.

With these limits the Camaldolese could occupy "tanto per la longitudine che per la latitudine [...] tanto terreno e prato necessario a colonne e scale stanti nel detto portico e edificio e da entrambe le parti delle colonne stesse". This last sentence makes us think that, according to the testament, it was foreseen the realization of one or more porticoes on via degli Angeli and/or on via del Castellaccio to be realized later:"e sia da procurarsi altra licenza e da farsi altra deliberazione poiché il luogo predetto o meglio portico da edificarsi e da costruirsi sopra detta via rimanga aperto nel modo e nella forma della pubblica costruzione esistente sopra la piazza di San Marco davanti all'ospedale di Lemmo in modo che sia libero e sempre aperto e chiunque possa avere adito e uscita dal predetto oratorio" [20]. 
For some reason unknown to us at the time of giving Brunelleschi the task of the project, priority was given to the execution of the oratory; the construction of the portico (or porticoes) along the public streets was presumably shelved (fig. 6).

\section{Brunelleschi and the Rotonda}

According the tradition Brunelleschi made some drawings and a model for the Oratorio degli Scolari, then lost. As reported in old documents: the Codice Rustici first of all [2 I] (fig. 7), and other older authors, starting with Giorgio Vasari "Fece ancora il modello del bizzarrissimo tempio degl'Angeli"' [22] and other writers later [23].

Fig. 7. Detail of the Rotonda and the Convento degli Angeli taken from the "Codice Rustici" by Marco di Bartolomeo Rustici, about the middle of the 15th century, preserved in the Major Archiepiscopal Seminary of Florence.

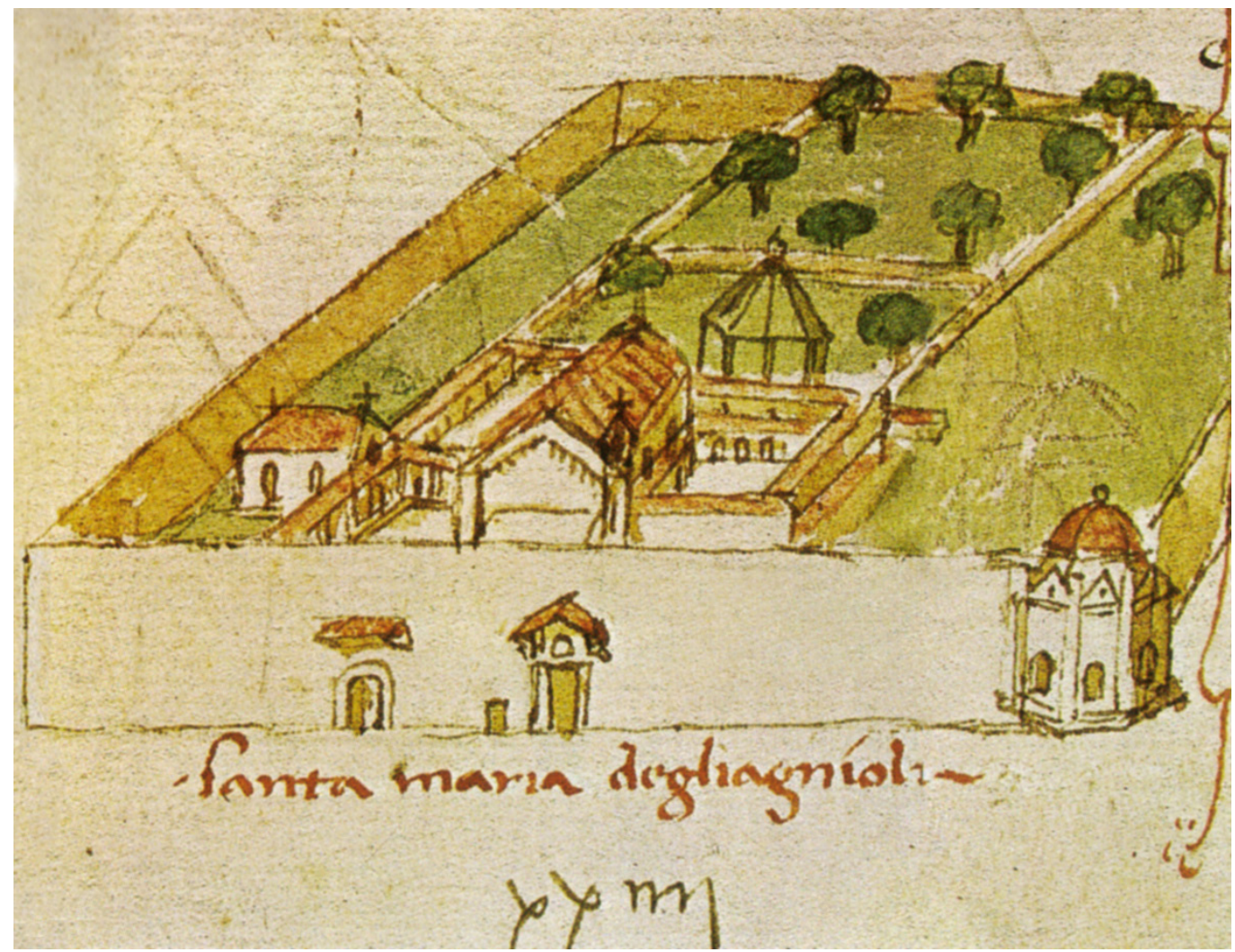

Rodolfo Sabatini, the architect who restored the Rotonda in 1932, in order to better visualize the intervention to the client (fig. 8), created a plaster model (fig. 9) of the sectioned half of the building [24]. The construction site of the Oratory began immediately in 1434, but soon stopped in 1437, when the Rotonda had reached the height of "over nine arms" [25]. Antonio Manetti, Brunelleschi's biographer, wrote "il tempio degli Agnoli [... preparato e fatto insino a dove oggi si truova, [... ] circa tutto intorno quanto alzano e pilastri delle cappelle" [26]. Reason for this suspension was the war of Florence against Lucca [27]. Other causes are perhaps to be found in the internal struggles following the return from exile of Cosimo il Vecchio or the death of the prior Ambrogio Traversari. Despite the admiration and interest of the contemporaries for the innovative architecture [28], the Rotonda remained completely abandoned for many centuries [29] (fig. 10). 
Fig. 8. Detail of a drawing by Rodolfo Sabatini of

1932 for the reconRotunda.

Fig. 9. Plaster model by Rodolfo Sabatini for

the reconstruction of

Brunelleschi's Rotonda of the Angels.
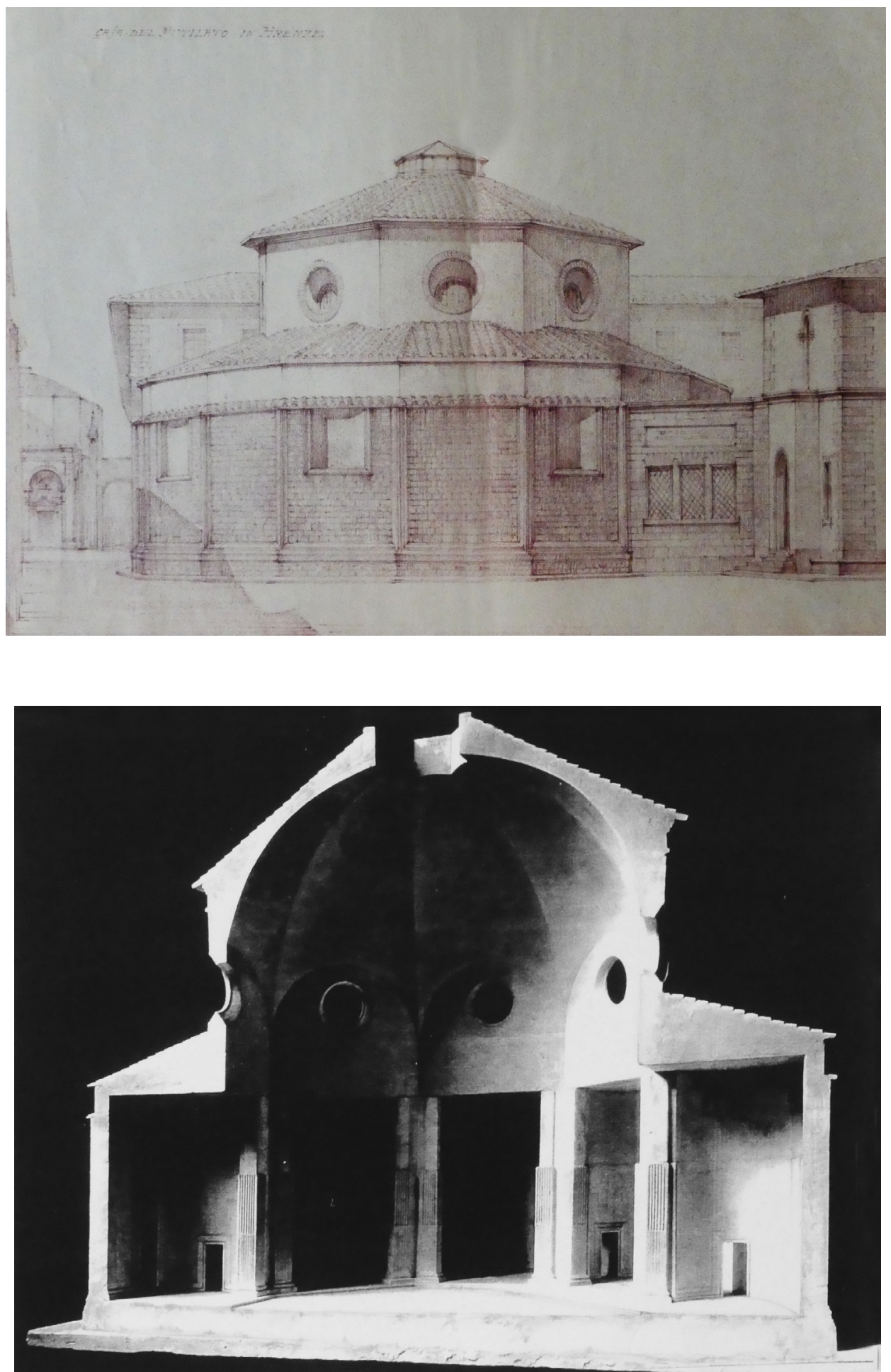
Fig. 10. Photo of about 1930 of Brunelleschi's Rotonda on the corner between via degli Alfani and via del Castellaccio before the reconstruction works.

Fig. I I. Giuliano da Sangallo, Codex Barberiniano Latino Vaticano, Sheet 15 verso, detail with the plan and a section of the Rotonda degli Angeli.
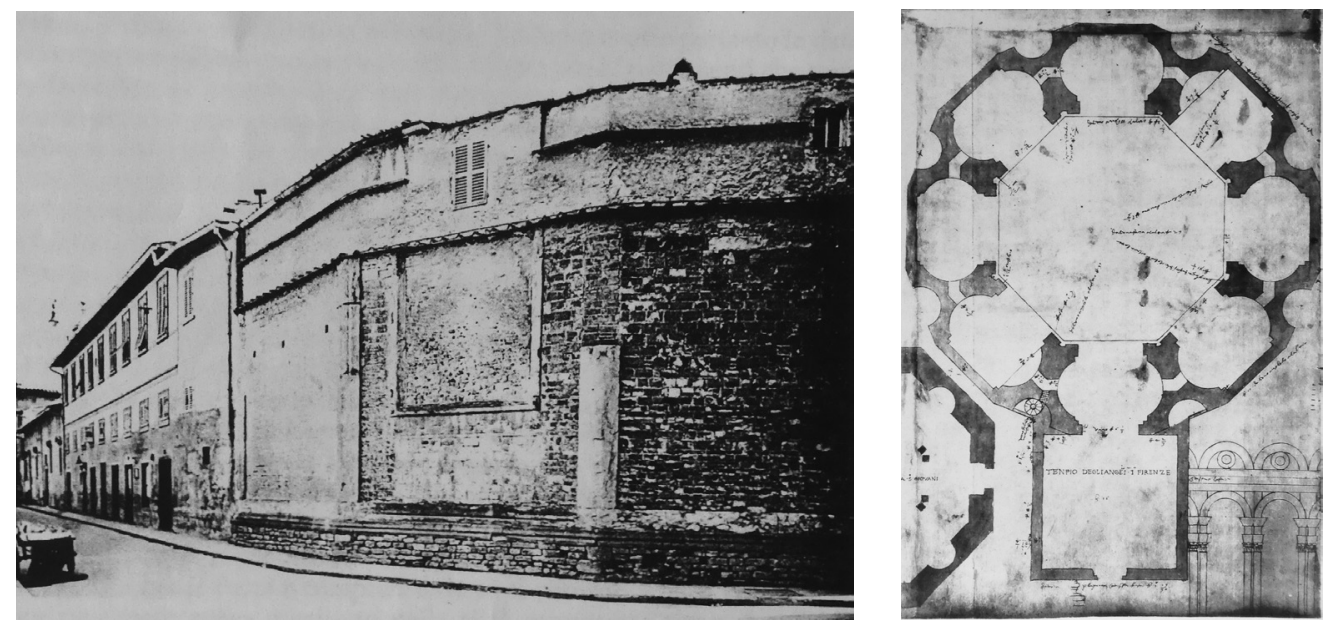

\section{Conclusions}

We do not know how Brunelleschi intended to complete the Rotonda; as is well known, the artist never expressed his ideas about the project openly and in full. The drawings and the model he made contained few details and there were many indications that Filippo explained "a voce" during the work. The model preserved in the Convent was simple and essential, perhaps there were no indications either for the entrance or for the choir; this would explain the differences between the two oldest internal representations of the Rotonda: the perspective of the Ashburnaham Codex and the interior in the Barberinian Codex [30] (fig. II): these drawings are personal interpretations of one or both authors [3 I]. Brunelleschi probably did not dedicate many ideas to the portico (or porticoes): he certainly did not think so in line with the entrance to the Rotonda. The available spaces would have foreseen its construction only next to the walls of the Convent on via del Castellaccio or along via degli Angeli (Via degli Alfani) [32].

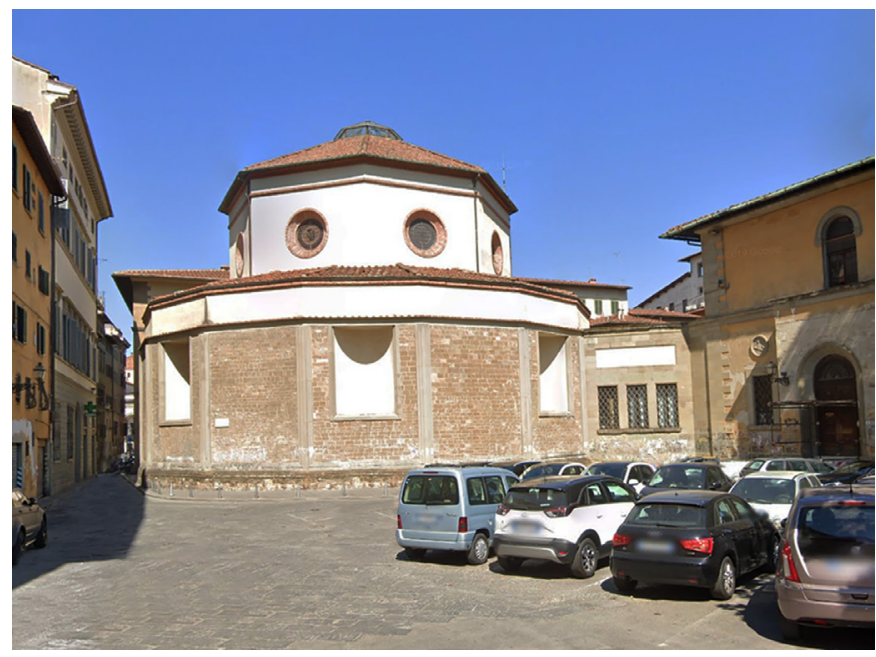

\section{Notes}

[I]The structures of the oldest Convent can be easily recognized even in the current plan [Savelli 1983].

[2] The cloistered was abolished around 1450.

[3] In 1378 on Tumulto dei Ciompi the rebels sacked the monastery because it was full of riches that many rich citizens of Florence had deposited here. 
[4] The Camaldolese monastery becomes the centre of an important school of "miniatori di Codici" unique, precious and wonderful works; famous painters live in the convent: Lorenzo Monaco who here paints a "Incoronazione della Vergine". Inside the monastery we find important works of art: a bronze urn by Ghiberti, a "Giudizio Universale" by Beato Angelico, two "Crocifissioni" by Andrea del Castagno and many others.

[5] Cosimo de' Medici had the "patrocinio" of an altar in the Monastery (Romby 1979, p. I0). Among the habitual visitors to the Convent are the men of letters Leonardo Bruni, Poggio Bracciolini and Carlo Marsuppini and Marsilio Ficino.

[6] Savelli writes about the cloisters of the Convento degli Angeli 1983, pp. 19-22.

[7]This word is found many times in the testament of 1433-34 on the Oratory and the Camaldolese Monastery.

[8] On Via del Castellaccio the Bargellini 1977 hypothesizes: "Abbiamo già detto, nel parlare di Via degli Alfani e di Piazza Brunelleschi, come nel «cafagrio» vicino esistesse un Tiratoio del Castellaccio, forse chiamato così per qualche torre ghibellina, diruta al tempo delle guerre civili. Quello di Castellaccio dovette essere un nome molto antico, che probabilmente passò dalla diruta torre alla incompiuta Rotonda" [Bargellini-Guarnieri 1977, p. 2 14]. Saalman 1993, p. 386, writes that the term Campaccio does not indicate a precise place, but generically and refers to free building land.

[9] The corner between Via degli Alfani andVia della Pergola was named Canto alla Catena because of the coat of arms of the Alberti family placed there, four chains joined in the middle by a ring [Bargellini 1977, p. 45]

[ I0] Until 1370 the Alberti family gave its protection to the Orbatelle hospice; after their exile the complex passed to the Arte della Lana [Bargellini 1977, p. 44]

[I I] At the Canto di Montiloro the Compagnia dell'Assunta (Monti d'oro from its coat of arms) had a tabernacle; next to the church of Santa Maria di Candeli there was an ancient convent of Augustinian nuns, now used as police station [Bargellini 1977, pp. 44-47].

[12] Most of the information on the testament are in: Saalman 1993, pp. 384-396; Savelli 1992, pp. I 3 ss.; Battisti I977, pp. 253 ss.; Miarelli Mariani 1974, p. 47. The complete history of the testament and the named characters can be found in: Linacher 1918-19, 1919-20. In the first testament dated I5 March 1433 we read: "Nell'oratorio 'e nei suoi edifici' dovranno essere ben visibili, 'dipinte e scolpite', le armi e le insegne della detta Arte (di Calimala) e della famiglia Scolari" [Savelli 1992, p. 39].

[13] A first request had been made by Pippo Spano to Pope Martino V [Saalman 1993, p. 384].

[14]The first idea of the two cousins Scolari was to build two monasteries in Tizzano and Vicchiomaggio [Savelli I 992, p. I3].

[ I 5] The translations of the original testament (kept at the State Archives of Florence, C.S. Diplomatico, Fondo S. Maria degli Angeli, dated 16 April 1434) are in: Savelli 1992, pp. 40-4I; Bass 1980, pp.477-484; Saalman 1993, pp. 452-453; Savelli 1992 pp. 4 |- 43 .

[16] The gate of Balla in the walls of Florence in the XI century was where now is the crossroads between via de' Pucci, via Bufalini and via dei Servi; this last street was created after I 256 joining in a straight line the gate of Balla with the church of SS. Annunziata. But via del Castellaccio always remained important if Brunelleschi aligned the portico of the Innocenti. The gate is called "di Balla" because of the presence in the area of tiratoio of the Arte della Lana and the intense traffic of wool bales that developed here [Fanelli 1973, p. 25]. The presence in this area of numerous tiratoi is explained by the ancient course of the Mugnone river, along via del Castellaccio [Pietramellara 1978, p. 42].

[17]Via Gino Capponi was first called via Orto dei Servi and via San Sebastiano.

[I 8] Saalman 1993, pp. 386-39I identifies the place Campaccio with the area free of buildings between via dei Servi, via degli Alfani and via del Castellaccio.

[19]The Rotonda would come into visual contact, almost aligned, with the Portico degli Innocenti.

[20] Savelli 1992, p. 42. The portico referred to is the external one of the former hospital of Lemmo or San Matteo (the current Accademia) in Piazza San Marco (figs. 2-4).

[2 I] Codice Rustici by Marco di Bartolomeo Rustici, circa mid- I5th century, preserved in the Major Archiepiscopal Seminary of Florence; Acidini-Gurrieri, 2018

[22] From "Vite del Vasari ..." (Ed. giuntina 1568 - reprint 1993, p. 345). Vasari himself writes of a drawing by Brunelleschi in his possession: "Le carte della pianta e del finimento del quale tempio a otto facce, di mano di Filippo, è nel nostro libro, con altri disegni del medesimo".

[23] Many authors speak of a drawing by Brunelleschi preserved in the Convent from the 17th century onwards [Miarelli Mariani 1975, pp. 35-48]

[24] The client was the Associazione Nazionale Militari Invalidi di Guerra. Sabatini presented the managers of the time with a plaster model that was kept in the Association's building until 1966, when, after the flood in November, it was lost.

[25] Linacher 1920, p. 10.

[26] Manetti 1976, p. 105

[27] Vasari, Le Vite, p. 345: "(l'Oratorio) rimase imperfetto e nella maniera che oggi si vede, per avere i Fiorentini spesi i danari (...) nella guerra che già ebbero co' Lucchesi”.

[28] Leon Battista Alberti, in BookVI, writes about Brunelleschi and the Rotonda: "mescolando elementi di pari proporzioni, linee rette con linee curve, luci con ombre... (egli cercò e riuscì di) ... ricavare, come da una congiunzione tra elementi maschili e femminili, qualcosa di nuovo". 
[29] In I 503 the perimeter of the Rotonda was covered by a roof that collapsed in I63 I. In I 563 Cosimo I wanted to set up the headquarters of the Accademia del Disegno in the complex, but the monks opposed this solution, thus beginning the slow and inexorable degradation of the Brunelleschian building.

[30] Huelsen 1910, fig. $15 \mathrm{~V}$.

[31] Bruschi 1972, p. I 4: here in appendix a "Ipotesi di ricostruzione grafica dell'alzato della Rotonda degli Angeli".

[32] See: Scalzo 200I, pp. 853-86I.

\section{References}

Acidini Cristina, Gurrieri Elena (2018). Firenze 1450-Firenze oggi. I luoghi di Marco Rustici orafo del Rinascimento. Firenze: Leo S Olschki.

Bargellini Piero, Guarnieri Enrico (1977). Le strade di Firenze. Firenze: Bonechi

Bass Geraldine (1980). Two documents on the Tempio degli Angeli. In De Angelis d'Ossat Guglielmo et al. (a cura di). Filippo Brunelleschi: la sua opera e il suo tempo. Firenze, 16-22 ottobre 1977. Firenze: Centro Di II, pp. 477-484

Battisti Eugenio. (1977). Filippo Brunelleschi. Milano: Electa.

Bruschi Arnaldo (1972). Considerazioni sulla "maniera matura" del Brunelleschi. In Palladio, nn I-IV, gen.-dic., pp. 89 - I 26.

Fanelli Giovanni ( 1973). Firenze, architettura e città. Firenze:Vallecchi.

Farulli Gregorio (17|0). Istoria cronologica del nobile e antico Monastero degli Angioli di Firenze. Firenze.

Huelsen Christian (19|0). Il libro di Giuliano da Sangallo - Codice Barberiniano Latino. Torino: Lipsia.

Linacher Arturo (1920). II "Tempio degli Scolari", estratto dagli Atti della Società Colombaria di Firenze (anni 1918-19 e 1919-20), Firenze: L'Arte della Stampa.

Manetti Antonio (1976). Vita di Filippo Brunelleschi. Milano: II Polifilo.

Miarelli Mariani Giuseppe ( 1974). II tempio fiorentino degli Scolari - Ipotesi e notizie sopra una irrealizzata opera brunelleschiana. In Palladio, nn. I.IV, gennaio-dicembre, pp.45-74.

Miarelli Mariani Giuseppe (1975). I disegni per la Rotonda degli Angioli: elementi per la ricomposizione del progetto di Michelangelo. In Antichità Viva, XIV, 1975, 2, pp. 35-48.

Millon Henry A. (1994). I modelli architettonici nel Rinascimento, in Rinascimento da Brunelleschi a Michelangelo - La rappresentazione dell'architettura, Bompiani, Milano.

Pietramellara Carla (1978). Alcuni aspetti dell'arte tarda del Brunelleschi, in Antichità Viva, XVII, I978, I, pp. 40-51.

Romby Giuseppina Carla (1979). Per costruire ai tempi del Brunelleschi - modi, norme e consuetudini del quattrocento fiorentino. Firenze: Clusf.

Saalman Howard (1993). Filippo Brunelleschi.The Buildings, Zwemmer, London.

Savelli Divo (1983). Il Convento di S.Maria degli Angeli a Firenze. Firenze:Tornatrè

Savelli Divo (1992). La Rotonda del Brunelleschi - Storia e documenti. Firenze: Esuvia,

Scalzo Marcello (1995). La ricostruzione della Rotonda del Brunelleschi tra memoria e invenzione. In AAVV. II disegno luogo della memoria. Atti del Convegno. Alinea: Firenze, pp. 21 5-234.

Scalzo Marcello (1996). Un "disegno-documento" da Giuliano da Sangallo ai nostri giorni: la pianta della Rotonda degli Angeli, Tesi di Dottorato, Università degli Studi di Firenze.

Scalzo Marcello (200 I). II portico della Rotonda degli Angeli di Brunelleschi: un'ipotesi. In Coppo S., Davico P. (a cura di). II disegno dei portici. Il disegno della città.Torino:Celid.

Vasari Giorgio (1993). Le Vite dei più eccellenti pittori, scultori e architetti (dall'edizione giuntina del I568). Roma: Newton.

\section{Author}

Marcello Scalzo, Università degli Studi di Firenze, marcello.scalzo@unife.it

To cite this chapter. Scalzo Marcello (2020). II Monastero camaldolese degli Angeli e la Rotonda di Brunelleschi: possibili connessioni/The Monastero camaldolese degli Angeli and the Rotonda of Brunelleschi: possible connections. In Arena A Arena M., Brandolino R G Colistra D Ginex G. Mediati D. Nucifora S. Raffa P. (a cura di) Connettere Un disegno per annodare e tessere. Atti del $42^{\circ}$ Convegno Internazionale dei Docenti delle Discipline della RoppresentozonelConnectng. Drowing for who ding relationships. Proceedings of the 42 th International Conference of Representotion Disciplines Teachers. Milano: FrancoAngeli, PD. 2674-2693. 